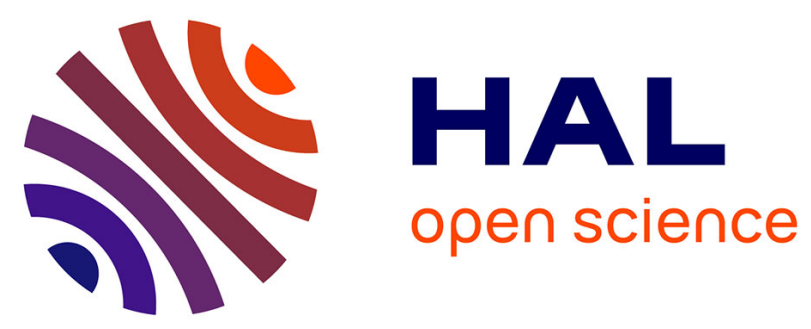

\title{
Control of geomorphic processes on 10Be concentrations in individual clasts: Complexity of the exposure history in Gobi-Altay range (Mongolia)
}

Riccardo Vassallo, Jean-François Ritz, Sébastien Carretier

\section{- To cite this version:}

Riccardo Vassallo, Jean-François Ritz, Sébastien Carretier. Control of geomorphic processes on 10Be concentrations in individual clasts: Complexity of the exposure history in Gobi-Altay range (Mongolia). Geomorphology, 2011, 135 (1-2), pp.35-47. 10.1016/j.geomorph.2011.07.023 . hal-00626702

\section{HAL Id: hal-00626702 \\ https://hal.science/hal-00626702}

Submitted on 6 Oct 2011

HAL is a multi-disciplinary open access archive for the deposit and dissemination of scientific research documents, whether they are published or not. The documents may come from teaching and research institutions in France or abroad, or from public or private research centers.
L'archive ouverte pluridisciplinaire HAL, est destinée au dépôt et à la diffusion de documents scientifiques de niveau recherche, publiés ou non, émanant des établissements d'enseignement et de recherche français ou étrangers, des laboratoires publics ou privés. 


\section{$1 \quad$ Control of geomorphic processes on ${ }^{\mathbf{1 0}} \mathrm{Be}$ concentrations in}

\section{2 individual clasts: complexity of the exposure history in Gobi-Altay \\ range (Mongolia)}

1 : ISTerre, CNRS, Université de Savoie, 73376 Le Bourget du Lac, France

2 : Géosciences Montpellier, CNRS, Université Montpellier 2, 34095 Montpellier, France

3 : Géosciences Environnement Toulouse, IRD, 31400 Toulouse, France

\section{Abstract}

The dating of alluvial landforms by cosmogenic nuclides requires distinguishing the pre-deposition inheritance from the post-deposition history of the clasts in the studied marker. Moreover, estimating catchment-scale erosion rates from the concentrations of cosmogenic nuclides in active alluvia requires a good knowledge of the local/regional relationships between rock exhumation and transport through space and time. This is still poorly known for timescales of tens of thousand years. In order to document the evolution of clast exhumation and transport rates through time, we analyze in situ ${ }^{10} \mathrm{Be}$ concentrations in boulders and cobbles from hillslopes to outlet of an arid mountainous catchment located in Gobi-Altay, Mongolia, strongly affected by global climatic changes during the Pleistocene-Holocene period. Samples were collected on bedrock, abandoned alluvial deposits, active colluvia and

22 alluvia. Our results show a large ${ }^{10} \mathrm{Be}$ scattering in the active river bed, consistent with a low 23 and discontinuous catchment erosion rate dominated by mass wasting and fluvial incision. On 
the contrary, pre-exposure signal within abandoned terraces is much more homogeneous, consistent with climatic pulses responsible of strong erosional events on hillslopes and rapid fluvial transport. These results show that exhumation/transport processes at the catchment scale vary in style and intensity through time as a consequence of climatic oscillations. The occurrence of abrupt climatic changes during short periods of time recorded by ${ }^{10} \mathrm{Be}$ concentrations in abandoned alluvia raise questions about the temporal applicability of catchment erosion rates derived from cosmogenic nuclide concentrations measured in sediments of active rivers. On the other hand, strong and short erosion events limit and homogenize the pre-exposure ${ }^{10} \mathrm{Be}$ signal in associated deposits like debris-flows, making them particularly suitable markers for dating in active tectonic and paleoclimatic studies.

Keywords: Cosmogenic radionuclides; River terraces; Hillslopes; Dating; Catchment erosion; Mongolia

\section{Introduction}

During the last two decades, thanks to the development of the geochronological methods and improvement in the accuracy of analytical measurements, many studies have focused on the determination of rates and frequencies of geomorphic processes in various tectonic/climatic contexts (e.g. Anderson et al., 1996; Burbank et al., 1996; Granger et al., 1997; Heimsath et al., 2001; Dunai et al., 2005; Von Blanckenburg; 2006, Belmont et al., 2007; Palumbo et al., 2009; Delunel et al., 2010; Matmon et al., 2010). However, further improvement in the understanding and quantification of these processes requires a close collaboration between geomorphologists and Quaternary geochronologists. To establish natural laws that explain the mechanisms and the characteristic timescales of the landscape evolution (bedrock exhumation, sediment dynamics, landform preservation), 
geomorphologists need more precise chronological data for reconstructing the history of geomorphic markers. In parallel, to improve the precision on landforms dating, Quaternary geochronologists need better knowledge of surface processes controlling the pre- and postdepositional histories of sediments.

Methods based on cosmogenic radionuclides $(\mathrm{CRN})$ for dating the exposure of landforms or for quantifying catchment-scale erosion rates are based on simplified models of exhumation, transport and deposition of sediments. In many cases, these models are too simplistic. For example, dating of alluvial markers using a limited set of clasts along a depthprofile is strongly limited if inheritance varies a lot from one clast to another (Repka et al., 1997; Ritz et al., 2006; Le Dorz et al., 2009) or if denudation rate is not well-constrained (Gillespie and Bierman, 1995). Further, , to estimate the catchment-scale erosion rates, we assume that $\mathrm{CRN}$ concentrations are at steady-state on the hillslopes and that $\mathrm{CRN}$ acquisition during fluvial transport is negligible (Brown et al., 1995; Granger et al., 1996). However, the significant scattering of CRN observed in distinct clasts of alluvial fans (e.g. Ritz et al., 2006; Owen et al., 2011; Schmidt et al., 2011) and along the fluvial system (Belmont et al., 2007) suggests that fluvial processes can contribute significantly and perturb the CRN signal in sediments.

Theoretical models have recently emphasized that the evolution of CRN in distinct clasts through the fluvial system could allow exhumation-transport rates to be quantified (Codilean et al., 2008; Gayer et al., 2008; Carretier et al., 2009a; Yanites et al., 2009). Nevertheless, there is a crucial lack of systematic analysis of CRN concentrations in clasts through a catchment.

Measuring CRN concentration in distinct clasts could provide a tool to analyse how spatial and temporal variations of the hillslope erosion rate are recorded in the cosmogenic signal, or, on the contrary buffered, along the fluvial system (Repka et al., 1997). A critical 
issue is the potential of CRN to document past variations in erosion rate. Inversely, it is difficult to determine the period of time over which the CRN-derived erosion rate applies. Schaller et al. (2004) reconstructed paleo-erosion rates from ${ }^{10} \mathrm{Be}$ concentrations in abandoned terraces of the River Meuse since 1.3Ma. These authors concluded that the CRN-derived hillslope erosion rate has a long response time after the tectonic and climatic perturbations. Braucher et al. (2003) modelled the effect of varying climates on ${ }^{10} \mathrm{Be}$ concentration evolution on hillslopes. They showed that ${ }^{10} \mathrm{Be}$-derived erosion rates can be significantly shifted and attenuated, compared to true erosion rate variations for long periods of times (16-100 ka). Niemi et al. (2005) also found that complete equilibration of CRN concentrations to new erosional conditions may take tens of thousands of years. On the other hand, landslides can generate stochastic variations in ${ }^{10}$ Be concentrations in river channels (Small et al., 1997; Niemi et al., 2005; Reinhardt et al., 2007; Binnie et al., 2007; Densmore et al., 2009; Ouimet et al., 2009; Yanites et al., 2009; Palumbo et al., 2011). Models suggest that these variations can be averaged in large catchments, and that a good estimation of catchment-average erosion rate can be obtained if the catchment area is sufficiently large (Yanites et al., 2009). However, other complexities may arise from large catchments, like long fluvial transport, sediment storage and recycling (e.g. Matmon et al., 2005; Kober et al., 2007).

Overall, the capacity of fluvial system to buffer short-term (landslides) and long-term (global climatic change) variations of hillslope erosion rates remains to be documented. A suitable field case to study this phenomenon requires strong temporal erosion rate variations, and well preserved river terraces formed cyclically during transitions of global climatic cycle.

The Ih Bogd massif, located in the Gobi-Altay mountain range in southwestern Mongolia, is a favorable site to understand the dynamics of catchment surface processes under an arid climate (Fig. 1). Situated in a desert region, this massif presents outstanding geomorphic features like a large preserved flat summit plateau, the absence of Quaternary 
glacial landforms, and the presence of abandoned strath terraces along the rivers. A localized granitic source (corresponding to the summit plateau) located above $3000 \mathrm{~m}$ allows tracing of the path of the alluvial sediments that compose the terraces cover and the present river bed.

The Ih Bogd massif belongs to the Gurvan Bulag mountain range, the easternmost part of the Gobi-Altay, where the great M8 Gobi-Altay earthquake occurred in 1957 (Florensov and Solonenko, 1965). Since the early 90's, several studies provided an important set of morpho-structural data (Baljinnyam et al., 1993; Cunningham et al., 1996; Kurushin et al., 1997; Bayasgalan et al., 1999a and b; Carretier et al., 2002; Vassallo et al., 2007a) and geochronological data (Ritz et al., 1995; Hanks et al., 1997; Ritz et al., 2003, 2006; Vassallo et al., 2005, 2007a and 2007b; Jolivet et al., 2007).

The Bitut catchment, the larger of Ih Bogd massif, is the best-studied one in terms of morphology, tectonics and geochronology (Figs. 1, 2). There, Vassallo et al. (2007a) carried out a topographic survey, a detailed mapping and a ${ }^{10} \mathrm{Be}$ analysis of the alluvial markers to study the activity of the Quaternary faulting bounding the massif. To quantify the surface processes that sculpted the catchment's topography, and analyze their rates and frequencies, from the long-term $\left(10^{3}-10^{5} \mathrm{yrs}\right)$ to the Present, we supplemented the existing database of Vassallo et al. (2007a) with a detailed analysis of landforms, with 13 new ${ }^{10} \mathrm{Be}$ data on bedrock, colluvia and alluvia.

Analyzing the distribution of ${ }^{10} \mathrm{Be}$ concentrations from the watersheds to the outlet, we address three main questions. 1) What are the differences in style and magnitude of present and ancient surface processes (bedrock exhumation, stocking of colluvia on the hillslopes, remobilization and transport within the drainage network)?. 2) What are the main processes controlling the erosion of a catchment in an arid landscape? Analyzing abandoned and active landforms at different settings along the catchment, we compare geomorphic rates as a function of altitude, local slope, surface roughness, proximity to the drainage network. 3) 
124 What is the impact of inherited ${ }^{10} \mathrm{Be}$ on the dating of "young" and "old" terraces? We discuss

125 the errors in the age calculation that can be generated by an incorrect interpretation of the preexposure history of the sediments of the alluvial landforms.

\section{Morpho-structural setting of Ih Bogd massif}

The Ih Bogd massif, culminating at $3957 \mathrm{~m}$, is the highest mountain of the Gobi-Altay range, in southwestern Mongolia (Fig. 1). The massif is $50 \mathrm{~km}$ long, $25 \mathrm{~km}$ wide, and forms a relief of $\sim 2 \mathrm{~km}$ between its flat summit surface and the surrounding piedmont. Located in one by oblique and reverse faults on both of its northern and southern sides (Cunningham et al., 1996; Bayasgalan et al., 1999b). Morpho-structural analysis (Vassallo et al., 2007a) and thermochronological data (Vassallo, 2006; Vassallo et al., 2007b) show that the massif built up during an in-sequence migration of fault activity from its central part towards its external boundaries. Upper Pleistocene-Holocene vertical slip rates along the active bounding faults are identical on both sides and of the order 0.1-0.2 mm/yr (Ritz et al., 2006), which is consistent with the horizontal summit plateau feature, interpreted as a remnant of a large

140 Jurassic peneplain surface (Jolivet et al., 2007) that has been uplifted during the late Cenozoic

141 (Vassallo et al., 2007b). The summit surface experienced very small runoff erosion, as shown

142 by the absence of tracks of ancient transverse drainage. Catchment erosion processes are 143 dominated by mass wasting and fluvial incision, creating the formation of deep canyons and a 144 series of natural dams in the narrow parts of the valleys (Fig. 3).

145 The preservation of the summit plateau from the erosion associated with the 146 catchment's growth is due both to the young age of the massif and to the aridity of the 147 regional climate during the Late Cenozoic. The permanence of an arid climate over this period 148 is proven by the absence of relevant Quaternary glacial morphologies and deposits, implying 
149 that glacial stages must be particularly dry. Thus, fluvial incision is limited to the short

150 interglacial stages (a few thousand years over $\sim 100$ ka cycles), associated with changing 151 hydrological conditions, resulting in the periodical formation and abandonment of alluvial

152 fans in the piedmont and alluvial terraces within the massif (Ritz et al., 1995; Carretier et al., 153 1998; Vassallo et al., 2005). Owen et al. (1999) provided a similar model based on climate 154 variability for sediment production and transfer through another mountain in Gobi-Altay. The 155 present climate is arid with less than $200 \mathrm{~mm} / \mathrm{yr}$ of precipitation (Hilbig, 1995), usually 156 concentrated in intense summer rainstorms. As a consequence, vegetation is rare and 157 dominated by sparse low grass, while trees grow only around small spring areas.

158 Alluvial surfaces are mainly formed by debris-flows constituted of rounded meter-size 159 boulders encased in a sandy-silty, matrix-supported deposit. Cover thicknesses vary from one 160 surface to another, ranging from a few meters up to a dozen meters. Most of the outcropping 161 boulders have a desert varnish at the surface, gradually vanishing from their tops towards the 162 ground, revealing a gradient of weathering due to the progressive lowering of the surrounding 163 matrix by wind deflation (Ritz et al., 2006). Some boulders have a more complex patina 164 distribution, indicating some remobilization during their exposure history at the surface 165 (Vassallo et al., 2007a).

166 Stepped strath terraces inside the massif are connected with large alluvial fans within 167 catchment outlets. In some catchments, strath terraces are preserved for several kilometers 168 along rivers, and their width can reach a hundred meters. Strath levels of different age diverge 169 along a vertical axis from the outlet to the middle reaches. In the downstream direction, 170 terrace treads have generally the same gentle slope of the strath levels that they cover. In a 171 cross-valley direction, terrace tread slopes become steeper due to the enhanced erosion 172 associated with the runoff coming from the above hillslopes. 
Alluvial fans are located within the piedmont at the outlet of the main catchments. The

174 surface area of each fan increases with the size of the source catchment, with an average of a

175 few tens of $\mathrm{km}^{2}$ and a maximum of the order of a hundred $\mathrm{km}^{2}$. Each catchment yields a

176 series of stepped alluvial fans of different ages (Carretier et al., 1998; Vassallo et al., 2005).

177 Their total thickness within the sedimentary basins is unknown, but it is reasonably of the

178 order of several hundred meters (Florensov and Solonenko, 1965). Younger alluvial fans

179 show a typical higher frequency/lower amplitude incision pattern with respect to the older

180 ones. The abundance of meter-size boulders at the surface is well correlated to the age of the

181 fans, diminishing on older ones, suggesting a progressive disintegration by weathering 182 processes (Ritz et al., 2006).

183

184

\section{Morphology of Bitut catchment}

The Bitut catchment has a surface of about $80 \mathrm{~km}^{2}$, and extends from the northern mountainous front at $1600 \mathrm{~m}$ to the edges of the summit plateau at $4000 \mathrm{~m}$ (Fig. 2). The Bitut river, the main river draining the massif, is $18 \mathrm{~km}$ long, with a main bend toward the middle reaches from a $\mathrm{N} 0{ }^{\circ} \mathrm{E}$ to a $\mathrm{N} 100^{\circ} \mathrm{E}$ direction. This river system is associated with a Quaternary alluvial fan of $120 \mathrm{~km}^{2}$ in the piedmont. The active riverbed is $150 \mathrm{~m}$ wide at the lower reaches, narrowing up to a few tens of meters at the middle reaches when it flows in a steep canyon carved in the bedrock (Figs. 3a, 3b). Alluvia are composed of coarse sand and rounded boulders with a maximum diameter of 2-3 m. Within the higher part of the catchment, a huge landslide triggered by the earthquake of 1957 (Florensov and Solonenko, 1965) affects an entire flank of the valley over a length of more than $8 \mathrm{~km}$. The frontal part of this landslide dammed the river leading to an abrupt change in the morphology of the valley and the formation of two lakes (Fig. 3c). 
The morphology of the interfluves is dominated by landslides and mass wasting processes, determining characteristic slopes of $\sim 30^{\circ}$. However, spatial variability of bedrock lithology and fracturing results in locally enhanced or lowered erosion of the topography. Colluvial material covering hillslopes is relatively finer (pebbles and cobbles) at low altitudes, and coarse-grained (boulders up to few meters) at high altitudes. Within the summit region of the massif, large blocks of bedrock at the edge of the plateau are exhumed by differential erosion and become unstable. Once these blocks collapse on to the slopes beneath, they form long corridors - about 10 to $50 \mathrm{~m}$ in width - whose genesis is likely to be controlled by gravitational movements associated with the freezing-unfreezing of the first few meters of the surface. Along the hillslopes, these boulders corridors laterally alternate with screes and outcropping parts of bedrock (Fig. 4).

At the outlet of the catchment we observed four stepped strath terraces (T1 to T4, from the oldest to the youngest) (Fig. 5 and Fig. 14 in Vassallo et al. (2007a)). Downstream, the surfaces of the two younger terraces (T4 and T3) connect with alluvial fan surfaces. The four terraces are vertically spaced out over a height of $\sim 80 \mathrm{~m}$ above the river bed. T4 is the only 212 terrace that is found on both sides of the river. It is formed by meter-size rounded granitic 213 boulders encased in an unconsolidated sand matrix, and shows well preserved bar-and-swale morphology. The thickness of the alluvial cover is unknown at this site, because the strath level is hidden by the present river deposits, but it is likely to be of the order of a few meters. Terraces T3 and T2 look similar to one another in terms of geometry and composition. They

217 form two clear steps in the topography of the left-bank, with large planar surfaces sloping 218 gently $\left(3-4^{\circ}\right)$ downstream. They are constituted by large boulders, similar to those of terrace T4, encased in a consolidated sandy-silty matrix. The alluvial cover of terrace T3 is a few meters thick, while that of terrace T2 varies between 10 and $12 \mathrm{~m}$. Terrace T1, the oldest observed, is much less preserved than T2 and T3 and appears discontinuously on the left 
bank. Boulders still outcrop from the matrix, but their aerial part is largely reduced with respect to the boulders of the younger terraces. The sedimentary cover is a few meters thick. Its tread surface has a relatively high downstream slope $\left(6^{\circ}\right)$. Well above these terraces, a wide sub-planar surface containing weathered boulders corresponds to the remnant of an ancient piedmont (P0) of the massif. This perched piedmont is several hundred meters above the present one due to the movement on the frontal reverse fault, and is limited by a thrust fault to the south.

Upstream of the outlet area, terrace T1 is not preserved, while the three younger terraces can be followed for several kilometers along the river. However, only the youngest terrace $\mathrm{T} 4$ shows a continuous pattern on both banks, keeping a planar geometry all along. 232 The sediment charge of the active river bed progressively decreases toward the middle reaches. This corresponds to the downstream filling of a canyon carved between the base of the river bed and terrace T4. The canyon is 25 mdeep at about $7 \mathrm{~km}$ from the outlet, where it is almost sediment-free (Fig. 3b). Upstream of this point, the canyon is dammed by a small landslide causing its partial filling by alluvia.

\section{IV. ${ }^{10}$ Be results}

For the ${ }^{10} \mathrm{Be}$ analysis of the Bitut catchment, we combine data collected on the alluvial terraces (indicated by letter $\mathrm{T}$ in figures) and along a vertical profile in the bedrock (BT) at the canyon site (Vassallo et al., 2007a), with a new set of thirteen rock samples (Figs. 2 and 6,

242 Table 1). This new set of samples includes bedrock (B) from the summit plateau and its 243 edges, colluvial boulders (C) on the hillslopes, and alluvial boulders and cobbles on the 244 perched piedmont (P0) and in the active river (A). With the exception of colluvia on the 245 hillslope, which are gneisses, all the new and old samples are granites coming from the 246 highest part (> $3000 \mathrm{~m}$ ) of the left flank of the main Bitut valley (Fig. 2). Samples were 
247 prepared following the chemical procedures described by Brown et al. (1991). ${ }^{10} \mathrm{Be}$ analyses 248 were performed at the Tandétron Accelerator Mass Spectrometry Facility, Gif-sur-Yvette 249 (INSU-CNRS, France) (Raisbeck et al., 1987). The ${ }^{10} \mathrm{Be}$ analyses were calibrated against 250 NIST Standard Reference Material 4325 using its certified ${ }^{10} \mathrm{Be} /{ }^{9} \mathrm{Be}$ ratio of $(2.68 \pm 0.14) \times 10^{-}$ $251{ }^{11}$. Production rates have been calculated following Stone (2000) using the modified scaling 252 functions of Lal (1991) and a ${ }^{10} \mathrm{Be}$ production rate in quartz of $4.5 \pm 0.3 \mathrm{at} / \mathrm{g} / \mathrm{yr}$ at sea level 253 and high altitude owing to the revaluated ${ }^{10} \mathrm{Be}$ half-life of $1.36 \mathrm{Ma}$ (Nishiizumi et al., 2007). 254 Where surrounding topography partially shields incoming cosmic rays, geomorphic scaling 255 factors have been calculated following Dunne et al. (1999). ${ }^{10} \mathrm{Be}$ data are presented as pre256 and post-deposit, in order to distinguish the respective contributions to the final ${ }^{10} \mathrm{Be}$ signal.

\section{IV.1 Pre-deposit ${ }^{10} \mathrm{Be}$}

\section{IV.1.1 Summit plateau}

Two granitic bedrock samples have been collected on the summit plateau, one within its central part (IB001) and one on its northern edge (MO-03-75) (Fig. 7a, 7b). The two samples show different ${ }^{10} \mathrm{Be}$ concentrations: $1.74 \pm 0.19 \mathrm{Mat} / \mathrm{g}$ for the first and $0.02 \pm 0.01$ Mat/g for the second. Although we only consider two samples in this zone, the difference in concentrations is qualitatively consistent with the intensities of the erosional processes that we describe. Indeed, it is obvious that a strong gradient of denudation rates exists between the edges of the plateau, constantly rejuvenated by the lateral growth of the catchments, and its central region, preserved from significant runoff and gravitational processes. Therefore, rock exhumation on the edges is rapid and variable in time at the scale of Quaternary climatic cycles, while in the central part of the plateau it is much slower and constant, and dominated by cryoturbation processes, as suggested by the polygonal soil pattern observed within the summit surface (Fig. 7b). 
Even though the stochasticity of the processes on the edge of the plateau does not allow us to generalize a precise rate for the rest of the watershed, we consider that sample MO-03-75 is representative of a relatively fast rock exhumation at the slope break. On the contrary, given the central position of sample IB001 on the plateau and the flatness of this area, we believe that its concentration reflects an average rate that can be applied to the entire flat surface. Considering a constant vertical denudation rate, at an altitude of $3900 \mathrm{~m}$, this concentration yields a long-term exhumation rate of the summit surface of $23.6 \pm 3 \mathrm{~m} / \mathrm{Ma}$. The lowering of this flat surface by exhumation is, therefore, extremely slow with respect to the surface uplift produced by tectonics, which is $600-700 \mathrm{~m} / \mathrm{Ma}$ on average since the MioPliocene (Vassallo et al., 2007b).

\section{IV.1.2 Colluvia}

On the northern flank of the higher part of the Bitut valley, within the first hundreds of meters below the summit plateau, three angular meter-size granitic boulders have been sampled (Fig. 7a). They are situated in one of the boulders corridors - many others characterize the hillslopes at this altitude - going from the plateau to the main drainage system. Their ${ }^{10} \mathrm{Be}$ concentrations increase downslope with the distance from the edge of the plateau. The highest boulder (MO03-59, $3620 \mathrm{~m}$ ) has a concentration of $0.46 \pm 0.07 \mathrm{Mat} / \mathrm{g}$, while the lowest (MO03-63, $3340 \mathrm{~m}$ ) has a concentration of $0.91 \pm 0.09 \mathrm{Mat} / \mathrm{g}$. We only refer to three samples and we are aware that more measurements would be necessary to have a better statistics. Nevertheless, two main arguments strongly suggest that the downstream ${ }^{10} \mathrm{Be}$ increase corresponds to transport time: 1- all the boulders have the same source - which is almost ${ }^{10} \mathrm{Be}$ free as shown by sample MO03-75 situated on the edge of the plateau at $3860 \mathrm{~m}$; and 2- they have followed the same path along the slope. For an average ${ }^{10} \mathrm{Be}$ surface production rate of $57.4 \pm 3.8 \mathrm{at} / \mathrm{g} / \mathrm{yr}$ at $3600 \mathrm{~m}$ on a $30^{\circ}$ slope, and considering that the 
production rate in the sample varies between this maximum value (when the boulder is in the present relative position) and about 10 times less (when the boulder is upside-down), and for a constant rolling movement, we estimate a travel time of the order of 20-30 ka for a vertical displacement of $0.5 \mathrm{~km}$. This yields a downslope transport rate of $15-25 \mathrm{~m} / \mathrm{ka}$.

\section{IV.1.3 Abandoned alluvia}

Two arguments concerning the sediments covering the youngest strath terrace T4 confirm the presence of inherited ${ }^{10} \mathrm{Be}$ in the boulders. Firstly, boulders of the alluvial cover have concentrations 10 times higher than the bedrock exposed just below them in the vertical canyon walls (weighted means of $0.189 \mathrm{Mat} / \mathrm{g}$ and $0.013 \mathrm{Mat} / \mathrm{g}$, respectively) (Fig. 8). Nevertheless, it cannot be excluded that a rejuvenation of the steep canyon by lateral collapse contributes to accentuate this difference. Secondly, for 3 boulders among 4 (2m diamter boulders), samples collected on the top and at the bottom show that the bottoms have similar or even higher concentrations than tops (Figs. 2, 6a). In this case, the only possibility to explain such a concentration distribution is to admit that the boulders have a complex preexposure history. This pre-exposure signal is also observed within the cobbles that were sampled along the depth-profiles within terraces $\mathrm{T} 3$ and $\mathrm{T} 2$, and more generally within the 8 depth-profiles carried out within the alluvial deposits of the mountain range (see Ritz et al., 2006). Indeed, even at $2 \mathrm{~m}$ depth, ${ }^{10} \mathrm{Be}$ concentrations are very similar for deposits of different ages ( 20 ka, $100 \mathrm{ka}, \sim 200 \mathrm{ka})$ and too large to be explained by in situ production by muons (Table 1). Moreover, since concentrations decrease exponentially at depth with little scattering, the quantity of inherited ${ }^{10} \mathrm{Be}$ must be relatively uniform for all the samples. Its approximate value is given by the asymptotic concentration towards which the exponential curves tend at depth (around 0.1-0.3 Mat/g, taking into account all the profiles). 
In the same way, looking at the distribution of surface concentrations within the four

322 strath terraces at the outlet of Bitut river, we observe that only two boulders on terrace T4, over the 30 sampled boulders, have much higher - more than 3 times higher - concentrations

than the mean (Fig. 6b, Table 1). Therefore, high inherited ${ }^{10} \mathrm{Be}$ concentrations are very rare for granulometric classes comprised between 0.1 and $2 \mathrm{~m}$ diameter. On the other hand, three samples on terraces T3 and T2 have lower concentrations than the mean. We interpret these lower concentrations as an effect of shielding (see next section).

All these results show that pre-exposure histories of abandoned alluvial deposits of the

Ih Bogd major catchment are similar. Moreover, the inherited concentration in alluvial deposits is significantly lower - up to 9 times lower - than that of the hillslope active colluvia situated at high altitude. This means that the hillslope erosional processes at the origin of main debris-flow events mobilize locally more than a few meters of material, bringing detrital sediments with low ${ }^{10} \mathrm{Be}$ concentration into the drainage network. In addition, similar transport time and similar exposure history seem to be characterizing transport dynamics for all granulometric classes between 0.1 and $2 \mathrm{~m}$ diameter.

\section{IV.1.3 Active alluvia}

Alluvia in the river bed have been collected between the middle reaches, downstream

339 of the region disturbed by landslides, and the outlet of the Bitut valley (Figs. 2, 6). Five 340 cobbles and boulders, ranging from $30 \mathrm{~cm}$ to $1 \mathrm{~m}$ diameter, show ${ }^{10} \mathrm{Be}$ concentrations between $3410.03 \mathrm{Mat} / \mathrm{g}$ and $1 \mathrm{Mat} / \mathrm{g}$. These concentrations are neither correlated with the size of the 342 samples nor with their position along the longitudinal profile of the river, nor with the 343 lithology. Three samples show minimum values very close to the concentrations obtained for 344 the bedrock at the edge of the plateau, while two samples show maximum values approaching 345 the hillslope colluvium with the highest concentration. These similarities suggest that river 
346 sediments are derived from two main types of dynamics on hillslopes: after bedrock 347 exhumation to surface, boulders that fall rapidly in the river after their detachment; and 348 boulders that remain trapped longer within the hillslope colluvia. We could observe directly 349 the first mechanism during a strong summer rainstorm during the fieldwork, when large 350 boulders came off the heights of the mountain and rolled downslope to the bottom part of the 351 valley situated nearly $1 \mathrm{~km}$ below. Therefore, these two dynamics (leading to opposite 352 tendencies in terms of inherited ${ }^{10} \mathrm{Be}$ concentrations) induce a more stochastic pre-exposure 353 history at Present than during the past major aggradation events recorded within the alluvial 354 landforms.

\section{IV.2 Post-deposit ${ }^{10} \mathrm{Be}$}

Within the strath terraces, at the outlet, mean surface ${ }^{10} \mathrm{Be}$ concentrations increase with the age of the terraces, except for $\mathrm{T} 1$ that shows lower concentrations than those of terraces

$\mathrm{T} 2$ and $\mathrm{T} 3$ (Fig. 5). For all terraces, ${ }^{10} \mathrm{Be}$ concentrations are relatively clustered around an average value, with few outliers showing much higher (T4) or lower values (T2 and T3) (Fig.

6). Samples with high concentration were interpreted as boulders that remained exposed much

362 more time than the others on the hillslopes. Samples with low concentration can be correlated to the fact that they were outcropping closer to the ground surface than the other samples. The

364 denudation of the depositional surface, estimated at $\sim 1 \mathrm{~m} / 100 \mathrm{ka}$ (Vassallo et al., 2007a), 365 exhumes and assembles at the surface clasts that were initially at different depths (Fig. 9). 366 This phenomenon has also been described on alluvial fans in Southern California, confirming 367 that the local denudation rate is partly determined by the initial lateral position in the alluvial 368 deposit - bar or swale - and by the dimensions of the aerial part of the clast (Matmon et al., 369 2006; Behr et al., 2010). 
While concentrations on terrace $\mathrm{T} 4$ do not show significant variations along the river,

371 terrace T3 is characterized by lower values toward the middle reaches, where its surface is steeper (Figs. 2, 6, 10). As shown by the absence of varnished patina over a larger band at the outcropping base of the boulders (Fig. 10), the denudation of the surface at this site is higher

374 in comparison with the flat surface of the same terrace at the outlet. This leads to a faster 375 exhumation of the boulders within the terrace, and consequently to their shorter exposure at 376 surface. If this longitudinal variability of the denudation rate were not taken into account, the analysis of the measured concentrations on this steeper portion would underestimate the age of terrace $\mathrm{T} 3$ by a factor 3 . The enhanced denudation rate on terrace $\mathrm{T} 1$ for the same topographic reasons explains an average concentration lower than that of the younger terrace $\mathrm{T} 2$.

The abandoned alluvial piedmont P0, much higher, older and steeper than all the other alluvial surfaces, has one sample in the range of the average concentration of terrace $\mathrm{T} 1$, and one that is half of this value. Since the production rate on P0 is $20-25 \%$ higher than the younger terraces at the outlet, even the sample with the highest concentration yields a lower apparent exposure age than terrace T1. This implies that, as expected given its relative age 386 and tread slope, this surface has reached a steady state concentration for a denudation rate that 387 is higher than that of terrace T1. The difference in steady-state concentrations between the 388 two samples on P0 also suggests that development of a more organized runoff pattern on a no389 longer planar surface creates zones of enhanced denudation rates that can locally be much 390 faster than the average on the same surface.

391 Thus, in such an alluvial context, two physical parameters have a main impact on the post-deposit shielding and the subsequent calculation of the exposure age of an alluvial landform: 1) the elevation of the top of the boulders over the ground level; and 2) the local 
slope of the topographic surface. These two parameters should be considered critically when sampling boulders on the surface.

\section{Discussion}

\section{V.1 Geomorphic processes and exposure}

A synthesis of different works in the Bitut catchment converges toward a scenario in which erosion processes in the Ih Bogd massif are characterized by different rates and paces depending on the spatial and temporal scale. Watershed retreat is determined by the drainage network growth, constantly active but particularly fast - several $\mathrm{m} / \mathrm{ka}$ - at the transition between glacial and interglacial periods when hydrological conditions change and flash flooding becomes dominant (Owen et al., 1998). River incision is mostly controlled by this phenomenon (more than mountain uplift), leading to a cyclic intense beveling of river bed in the middle reaches with lateral retreat of $100 \mathrm{~m}$ at the catchment head and bedrock canyons of more than $25 \mathrm{~m}$ depth created in less than $5 \mathrm{ka}$ (cf. Vassallo et al., 2007a; Carretier et al., 2009b) (Figs. 3b, 8). During the interglacial stages, the enhanced river incision rate triggers periods of hillslope instability expressed by large landslides, up to $8 \mathrm{~km}$ long when the geological structures are favorably oriented with respect to the axis of the valley - for example a parallel bedding/foliation dipping downslope (Fig. 3c), or local collapses. The style and intensity of present geomorphic processes at catchment scale are, therefore, a consequence of the recent Holocene incision.

Concerning sediment production and transport, on the basis of the geomorphic and CRN analysis we propose the following scenario. Recent (last 4-5 ka) exhumation rates are slow on average. Hillslope residence time and river transport rate vary considerably from one clast to another because of the strong climatic variability between long dry seasons and episodic summer storms, and because of a high number of "sinks" along the catchment - 
419 boulder corridors, dams, ephemeral basins created by landslides and collapses - where

420 sediments can be trapped for long periods. On the contrary, alluvial covers on strath terraces 421 are associated with strong erosion events that remove a thick layer on hillslopes - locally 422 several meters - and quickly transport these sediments in the river. Consequently, during 423 these periods, the clast-to-clast inheritance and variance is smaller on hillslopes and in river 424 sediments.

Denudation processes on the abandoned alluvial terraces appear much slower and stable through time. These processes are dominated by wind deflation and runoff, as shown by the distribution of the desert varnish at the top of the outcropping boulders. The consequent lowering of the silty-sandy matrix leads to the progressive exhumation of originally deeper encased boulders characterized by lower ${ }^{10} \mathrm{Be}$ concentrations. For subhorizontal terraces $\left(<5^{\circ}\right.$ slope $)$ having experienced one or more climatic cycles, denudation rates are of the same order $(0.6-0.7 \mathrm{~m} / 100 \mathrm{ka})$. On the other hand, steeper terraces - or steeper parts of them - undergo denudation rates of more than $1 \mathrm{~m} / 100 \mathrm{ka}$, and their dating by CRN is problematic if this value cannot be constrained with precision.

The superficial processes leading to the formation of the strath terraces are characterized by localized strong erosion of the hillslopes and rapid transport of the sediments through the drainage network. These processes produce minimum pre-exposure CRN concentration before abandonment, and make the alluvial landforms suitable geomorphic markers for dating. Inherited CRN concentrations in old alluvial landforms (>100 ka) show 439 constant values that are smaller than $10 \%$ of the total concentrations. Young terraces and fans 440 (<20 ka) contain alluvia with significant quantities of inheritance - sometimes more than 50\% 441 of the total concentration - but since their genesis dynamics is the same as the older ones, one 442 can expect that the average inheritance should be also similar. If this value can be estimated 443 from the old alluvial landforms by the analysis of the distribution of the concentration at 
444 depth, it can eventually be subtracted from the total ${ }^{10} \mathrm{Be}$ concentration for dating the young 445 alluvial landforms.

446 On the other hand, the high variability in the ${ }^{10} \mathrm{Be}$ concentrations in sediments of the 447 active channel raises questions about their representativeness of the long-term hillslope 448 erosion. Assuming a simple local constant denudation rate model, ${ }^{10} \mathrm{Be}$ concentration in river 449 sediments would theoretically allow estimation of the Bitut catchment mean erosion rate over 450 the last several thousands years (Brown et al., 1995; Granger et al., 1996). The numerical 451 calculation derived from the mean concentration of the active alluvia yields a rate of $\sim 0.61$ $452 \mathrm{~m} / \mathrm{ka}$ for an apparent age of $\sim 10 \mathrm{ka}$. However, our observations and data show that this 453 approach does not apply in Bitut catchment at least for the present day, where sediment 454 production and transport are very discontinuous and where sediments exhumed at different 455 periods of time could be mixed in the active river. Consequently, the mean ${ }^{10} \mathrm{Be}$ concentration 456 is not easily linked to a mean catchment-average erosion rate, nor to a well defined averaging 457 period.

Since alluvia covering strath terraces have more homogeneous pre-exposure histories, 459 we tested this approach to estimate a mean paleo-erosion rate of the catchment associated to 460 the last significant debris-flow event (5 ka). To calculate this rate, we used the mean inherited $461{ }^{10} \mathrm{Be}$ estimated from terrace $\mathrm{T} 4$. We calculate a paleo-erosion rate of $\sim 0.22 \mathrm{~m} / \mathrm{ka}$ for an 462 apparent age of $\sim 3 \mathrm{kyr}$, i.e. since 8 to $5 \mathrm{ka}$. This means that the theoretical interval concerned 463 is probably larger than the "instantaneous" event of $5 \mathrm{ka}$, including periods of different 464 erosion intensity. Nevertheless, the impact of this strong erosion is likely to be of the first 465 order on the inherited ${ }^{10} \mathrm{Be}$ of the abandoned alluvia.

The difference in pre-exposure concentrations between active and abandoned alluvia could be interpreted in two different ways. The first interpretation is that active alluvia have, on average, higher concentrations resulting from slow erosion and transport in the catchment. 
The large scattering in concentrations would therefore be related to episodic transport and

470 residence on hillslopes and in the channel, as suggested by the concentrations pattern in the 471 active colluvia. In this case, CRN concentrations in channel sediments would not give an 472 accurate estimate of hillslope erosion rate because a large part of CRN concentrations would 473 be acquired during transport.

474 The second interpretation is that CRN concentrations in the active channel include 475 clasts eroded on hillslopes during the last significant erosion event and clasts exhumed during 476 a previous period of slow hillslope erosion. In this case large differences in CRN 477 concentrations would result from a mix between two erosion periods on hillslopes of different 478 intensities rather than from stochastic transport in the channel. If true, the average CRN 479 concentration would give an estimate of the long-term hillslopes erosion rate over a period of $480 \sim 10 \mathrm{ka}$, integrating variations over periods of low and high erosion rates. In parallel, average inheritance determined in the abandoned alluvia would allow estimation of a stronger catchment erosion rate integrating a shorter period of time $(\sim 3 \mathrm{kyr})$ before and during the Holocene climatic pulse. In other words, a combined analysis on active and abandoned alluvia 484 should enable us to reconstruct the evolution of the erosion rate.

V.II Inherited ${ }^{10}$ Be impact on young and old terraces dating be estimated by the analysis of the distribution of the concentrations at depth (Anderson et al., 489 1996). The presence of inherited ${ }^{10} \mathrm{Be}$, if neglected, can induce significant errors on the dating 490 of "young" terraces - less than few tens of thousands years - but also "old" terraces approaching the steady state concentration.

When the pre-exposure time of the sediments is of the same order or longer than the 493 post-deposit exposure, young terraces can contain high fractions of inherited ${ }^{10} \mathrm{Be}$ (e.g. Le 
Dortz et al., 2009). This is the case for boulders of T4 in Bitut valley, or for young alluvial

495 fans on the southern side of Ih Bogd (Vassallo et al., 2005). If one does not take into account 496 the inheritance factor, the calculated age of the alluvial surface can overestimate, by more 497 than $100 \%$ the real age. Two cases are possible: if the inheritance is quite homogeneous and 498 can be precisely estimated, one can calculate the age by simply subtracting this quantity from 499 the total concentration (Anderson et al., 1996); or, if the inheritance is high but cannot be 500 precisely determined (scattering in the concentrations) it is possible to calculate a maximum 501 age by choosing the lower concentration sample (Vassallo et al., 2007a). Inheritance is also a perturbing element for the dating of old alluvial deposits, where it represents only a small part of the total concentration. The concentration of a sample, for a 504 given production and denudation rate, tends sooner or later to a steady-state determined by the 505 equilibrium between ${ }^{10} \mathrm{Be}$ gains (cosmogenic production) and losses (radioactive decay and 506 surface denudation). An initial quantity of inherited ${ }^{10} \mathrm{Be}$ implies that the CRN concentration increases through time, passes by a maximum and then tends very slowly toward the steadystate value. During the growth phase, the CRN concentration evolution is about the same as in 509 the case without inheritance, but offset by a quantity equal to the inherited CRN (Fig. 11). 510 Therefore, by neglecting inheritance, the risk is to consider a sample at the steady-state while actually its concentration is still increasing. Such a misinterpretation will induce an overestimation of the in-situ denudation rate and, consequently, an even more important over513 estimation of the minimum age of the surface. It is important to note that, if steady-state is 514 assumed for interpreting CRN concentrations, an error of less than $10 \%$ on the estimation of 515 the inheritance value or of the denudation rate yields considerable changes in the theoretical curves of concentration evolution for ages older than $\sim 100 \mathrm{ka}$ (Fig. 11). Therefore, in absence 517 of other independent ages or concentrations of other CRNs $\left({ }^{26} \mathrm{Al}\right.$ or ${ }^{21} \mathrm{Ne}$, for example), the 518 only way to establish if the CRN concentration of a surface has reached a steady-state or not 
519 is to compare it with that of younger or older surfaces, and analyze the relationships between

520 the relative morphological ages and the respective concentrations.

521

522

524

525

\section{Conclusion}

The Ih Bogd massif in the Gobi-Altay range is a particularly well-suited site to study the dynamics of catchment surface processes under an arid climate and to evaluate potentialities and limits of cosmogenic nuclides to quantify geomorphic processes. Erosion and transport processes in this massif vary in style and magnitude under the control of Quaternary climatic fluctuations. At present and during most of the time, the exhumation rate of rocks is slow and constant on average, while the transport of sediments is highly stochastic because of the numerous potential traps on hillslopes and in the drainage network. During past climatic pulses occurring in the interglacial periods, associated with different hydrological conditions, erosional events were much more intense and localized in time, and exhumation and transport were rapid. This variability in the landscape dynamics through time results in different pre-exposure histories for sediments in abandoned alluvial landforms produced by the main erosional events - and for active alluvia. Do the differences in CRN concentrations reflect the evolution of the catchment erosion rate during different periods, during climatic pulses and over a longer time-span? Or are they the result of different rates of transport on hillslopes and in the drainage network? Our results do not enable definite discrimination between these scenarios, even though the comparison with present processes and the concentration pattern in the active colluvia seems more consistent with the latter one. Quantifying past erosion and transport processes in catchments requires further investigations combining other CRNs on different alluvial systems.

Considering our results in the perspective of the dating of the abandoned alluvial landforms, we insist on the importance of a detailed 
geomorphic/stratigraphic/sedimentological analysis at the catchment and at the local scale. A

545 good knowledge of the pre-deposit processes (exhumation, transport dynamics) and of the 546 post-deposit processes (surface denudation, burying, sediment remobilization, soil processes)

547 is required for a correct sampling and interpretation of the cosmogenic data, prior to 548 mathematical inversions of the data. For "young" deposits, ${ }^{10} \mathrm{Be}$ inheritance can cause 549 apparent exposure ages to be several times higher than true ones. For "old" deposits, small 550 errors on the estimation of the inheritance or the denudation rate can lead to considerable age over-estimation or under-estimation. For suitable deposits, sampling both at surface and at depth - or at the bottom of the boulders - is therefore fundamental for a better quantification of the complex exposure history of the sediments, and thus for correct interpretation of the 554 concentrations in terms of ages.

\section{Acknowledgments}

We would like to acknowledge R. Braucher and D. Bourlès for fruitful discussions and for the help in preparation and measurements of the samples, and all the Mongolian team for their assistance during the fieldwork. We are also thankful to L. Palumbo and L. Owen for

560 their constructive reviews that helped to improve the manuscript.

\section{References}

Anderson, R.S., Repka, J.L., Dick, G.S., 1996. Dating depositional surfaces using in

564 situ produced cosmogenic radionuclides. Geology 24, 47-51. 
1993. Ruptures of major earthquakes and active deformation in Mongolia and its surroundings. Geol. Soc. Am., Memoir 181, p. 62.

Bayasgalan, A., Jackson, J., Ritz, J-F., Carretier, S., 1999a. 'Forebergs', flowers structures, and the development of large intra-continental strike-slip fault: the Gurvan Bogd fault system in Mongolia. J. Struct. Geol. 21, 1285 - 1302.

Bayasgalan, A., Jackson, J., Ritz, J-F., Carretier, S., 1999b. Field examples of strikeslip fault terminations in Mongolia and their tectonic significance. Tectonics 18, 394-411.

Belmont, P., Pazzaglia, F.J., Gosse, J.C., 2007. Cosmogenic 10Be as a tracer for hillslope and channel sediment dynamics in the Clearwater River, western Washington State. Earth Planet. Sci. Lett. 264, 123-135.

Hudnut, K.W., Kendrick, K.J., Platt, J.P., Sharp, W.D., Weldon, R.J., Yule, J.D., 2010. Uncertainties in slip-rate estimates for the Mission Creek strand of the southern San Andreas fault at Biskra Palms Oasis, southern California. GSA Bulletin 122,1360-1377, doi: 10.1130/B30020.1 
593 measurements at great depths : implications for production rates by fast muons. Earth Planet. 594 Sci. Lett. 211, 251-258.

595

Brown, E.T., Edmond, J.M., Raisbeck, G.M., Yiou, F., Kurz, M.D., Brook, E.J., 1991.

597 Examination of surface exposure ages of Antarctic moraines using in situ produced ${ }^{10} \mathrm{Be}$ et $598{ }^{26}$ Al. Geochim. et Cosmochim. Acta 55, 2699-2703.

599

601 rates determined from the accumulation of in situ-produced ${ }^{10} \mathrm{Be}$ in the Luquillo experimental 602 forest, Puerto Rico. Earth Planet. Sci. Lett. 129, 193-202.

603

604

Burbank, D.W., Leland, J., Fielding, E., Anderson, R.S., Brozovic, N., Reid, M.E., 605 Duncan, C., 1996. Bedrock incision, uplift, and threshold hillslopes in the northwest Himalaya. Nature 379, 505-510.

607

Carretier, S., Lucazeau, F., Ritz, J-F., 1998. Approche numérique des interactions 609 entre climat, tectonique et érosion. Exemple de la faille de Bogd, Mongolie. Comptes Rendus de l'Académie des Sciences 326, 1-7.

611 Int. 148, 256-277. 
Carretier, S., Regard, V., Soual, C., 2009a. Theoretical cosmogenic nuclide

617 concentration in river bed load clasts: Does it depend on clast size? Quaternary 618 Geochronology 4, 108-123.

619

Carretier, S., Poisson, B., Vassallo, R., Pepin, E., Farias, M., 2009b. Tectonic 621 interpretation of transient stage erosion rates at different spatial scales in an uplifting block. J.

622 Geophys. Res., 114, F02003, doi:10.1029/2008JF001080.

623

624

Codilean, A.T., Bishop, P., Stuart, F..M., Hoey, T.B., Fabel, D. Freeman, S.P.H.T., 625 2008. Single-grain cosmogenic Ne-21 concentrations in fluvial sediment reveal spatially 626 variable erosion rates. Geology 36, 159-162, doi: 10.1130/g24360a.1.

627

628

Cunningham, W.D., Windley, B.F., Dorjnamjaa, D., Badamgarov, J., Saandar, M., 629 1996. Late Cenozoic transpression in southwestern Mongolia and the Gobi Altai-Tien Shan connection. Earth Planet. Sci. Lett. 140, 67-81.

631

632

Delunel, R., Van der Beek, P.A., Carcaillet, J., Bourlès, D.L., Valla, P.G., 2010. Frostcracking control on catchment denudation rates: insights from in situ produced $10 \mathrm{Be}$ concentrations in stream sediments (Ecrins-Pelvoux massif, French Western Alps). Earth Planet. Sci. Lett. 293, 72-83.

636

Densmore, A.L., Hetzel, R., Ivy-Ochs, S., Krugh, W.C., Dawers, N., Kubik., P., 2009.

638 Spatial variations in catchment averaged denudation rates from normal fault footwalls. 
642 aridity in the Atacama Desert revealed by exposure dating of erosion-sensitive landforms. 643 Geology 33, 321-324.

644

Dunne, J., Elmore, D., Muzikar, P., 1999. Scaling factors for the rates of production of 646 cosmogenic nuclides for geometric shielding and attenuation at depth on sloped surfaces. 647 Geomorphology 27, 3-11.

648

650 of Commer., Washington D.C., 424p.

651

Gillespie, A.R., Bierman, P.R., 1995. Precision of terrestrial exposure ages and erosion rates estimated from analysis of cosmogenic isotopes produced in situ. J. Geophys. Res., 100, B12, 24637-24649.

655

656

Gayer, E., Mukhopadhyay, S., Meade, B. J., 2008. Spatial variability of erosion rates 657 inferred from the frequency distribution of cosmogenic He-3 in olivines from Hawaiian river 658 sediments. Earth Planet. Sci. Lett. 266,303-315.

659

660 Granger, D.E., Kirchner, J.W., Finkel, R.C., 1996. Spatially averaged long-term 661 erosion rates measured from in situ-produced cosmogenic nuclides in alluvial sediment. The 662 Journal of Geology 104, 249-257. 
665 New River, Virginia, measured from differential decay of cosmogenic ${ }^{26} \mathrm{Al}$ and ${ }^{10} \mathrm{Be}$ in cave666 deposited alluvium. Geology 25, 107-110.

667

Hanks, T., Ritz,. J-F., Kendrick, K.., Finkel, R.C., Garvin, C., 1997. Uplift rates in a

continental interior: faulting offsets of a $\sim 100 \mathrm{Ka}$ abandoned fan along the Bogd fault,

670 southern Mongolia. Proceedings of the Penrose Conference on the Tectonics of Continental

671 Interiors. 23-28 September 1997, Brian Head Resort, Cedar City, Utah.

672

Heimsath, A.M., Dietrich, W.E., Nishiizumi, K., Finkel, R.C., 2001. Stochastic processes of soil production and transport: erosion rates, topographic variation and cosmogenic nuclides in the Oregon Coast Range. Earth Planet. Sci. Lett. 26, 531-552.

676 Academic Publishing, Amsterdam, pp.13-32.

679

Jolivet, M., Ritz, J-F., Vassallo, R. , Larroque, C., Braucher, R., Todbileg, M.,

Chauvet, A., Sue, C., Arnaud, N., De Vicente, R., Arzhannikova, A., Arzhannikov, S., 2007. Denudation rates and a topography-driven rainfall threshold in northern Chile: Multiple 
690 Bayarsayhan, C., Hudnut, K.W., Lin, J., 1997. The surfaces rupture of the 1957 Gobi-Altay, 691 Mongolia, earthquake. Geol. Soc. Am. Spec. Pap., 320 143p.

692

693 Lal, D., 1991. Cosmic ray labeling of erosion surfaces : in situ nuclide production rates 694 and erosion models. Earth Planet. Sci. Lett. 104, 424-439.

695

696

Le Dortz, K., Meyer, B., Sébrier, M., Nazari, H., Braucher, R., Fattahi, M., Benedetti,

L., Foroutan, M., Siame, L., Bourlès, D., Talebian, M., Bateman, M.D., Ghoraishi, M., 2009. Holocene right-slip rate determined by cosmogenic and OSL dating on the Anar fault, Central Iran. Geophys. Journ. Int. 179, doi :10.1111/j.1365-246X.2009.04309.x 803-817. abandoned fan surfaces, Southern California. Quaternary Research 66, 109-118. 
714 bedrock landslides on cosmogenically determined erosion rates, Earth Planet. Sci. Lett. v. $237,480-498$.

Nishiizumi, K., Imamura, M., Caffee, M.W., Southon, J.R., Finkel, R.C., McAninch, J., 2007. Absolute calibration of 10Be AMS standards. Nucl. Instrum. Methods B258, 403413.

Ouimet, W.B., Whipple, K.W., Granger, D.E., 2009. Beyond threshold hillslopes:

Channel adjustment to base-level fall in tectonically active mountain ranges. Geology 37, 579-582, doi:10.1130/G30013A.1.

Owen, L.A., Richards, B., Rhodes, E.J., Cunningham, W.D., Windley, B.F.,

Badamgarav, J., Dorjnamjaa, D., 1998. Relic permafrost structures in the Gobi of Mongolia: age and significance. Journal of Quaternary Science 13, 539-548.

Owen, L.A., Cunningham, D., Windley, B.F., Badamgarov, J., Dorjnamjaa, D., 1999. The landscape evolution of Nemegt Uul: a late Cenozoic transpressional uplift in the Gobi and Stability: Perspectives on Long-term Landscape Development, Geological Society, London, Special Publications, 162, pp. 1-18.

734

Owen, L.A., Frankel, K.L., Knott, J.R., Reynhout, S., Finkel, R.C., Dolan, J.F., Lee, J., 

doi:10.1016/j.geomorph.2010.10.024

739

catchment-wide denudation rates derived from cosmogenic 10Be in two mountain ranges at

the

margin of

NE Tibet.

Geomorphology

117

$130-142$, doi:10.1016/j.geomorph.2009.11.019.

744

Palumbo, L., Hetzel, R., Tao, M., Li, X., 2011. Catchment-wide denudation rates at the margin of NE Tibet from in situ-produced cosmogenic 10Be. Terra Nova 23, 42-48.

747

748

\section{9}

750

751

752

753

754

755

756

757 758

759

F., Enkhtuvshin, B., 1995. Slip rates along active faults estimated with cosmic-ray-exposure

761

Raisbeck, G.M., Yiou, F., Bourlès, D.L., Lestringuez, J., Deboffe, D., 1987. Measurements of ${ }^{10} \mathrm{Be}$ and ${ }^{26} \mathrm{Al}$ with a Tandetron AMS facility. Nuclear Instruments and Methods 29, 22-27.

2007. Interpreting erosion rates from cosmogenic radionuclide concentrations measured in rapidly eroding terrain. Earth Surf. Process. Landforms 32, 390-406.

Repka, J.L., Anderson, R.S., Finkel, R.C., 1997. Cosmogenic dating of fluvial terraces, Fremont River, Utah. Earth Planet. Sci. Lett. 152, 59-73.

dates: Application to the Bogd fault, Gobi-Altaï, Mongolia. Geology 23, 1019- 1022. 
Ritz, J-F., Bourlès, D., Brown, E.T., Carretier, S., Chery, J., Enhtuvushin, B., Galsan,

764 P., Finkel, R.C., Hanks, T.C., Kendrick, K.J., Philip, H., Raisbeck, G., Schlupp, A., Schwartz,

765 D.P., Yiou, F., 2003. Late Pleistocene to Holocene slip rates for the Gurvan Bulag thrust fault

766 (Gobi-Altay, Mongolia) estimated with ${ }^{10}$ Be dates. J. Geophys. Res. 108(B3), 2162, 767 doi :10.1029/2001JB000553.

Ritz, J-F., Vassallo, R., Braucher, R., Brown, E.T., Carretier, S., Bourlès, D.L., 2006.

Using In Situ-Produced 10Be to Quantify Active Tectonics in the Gurvan Bogd Mountain

Produced Cosmogenic Nuclides and Quantification of Geological Processes", edited by

Siame, L., Bourlès, D.L., Brown, E.T. pp. 87- 110.

774

Schaller, M., Von Blanckenburg, F., Veldkamp, A., Van den Berg, M.W.,. Hovius, N.,

776

777

778

779

780

781

782

783

784

785

Schmidt, S., Hetzel, R., Kuhlmann, J., Mingorance, F., Ramos, V.A., 2011. A note of caution on the use of boulders for exposure dating of depositional surfaces. Earth Planet. Sci. Lett. 302, 60-70.

Small, E.E., Anderson, R.S., Repka, J.L., Finkel, R., 1997. Erosion rates of alpine bedrock summit surfaces deduced from in situ ${ }^{10} \mathrm{Be}$ and ${ }^{26} \mathrm{Al}$. Earth Planet. Sci. Lett. 150, $413-425$. 

105(B10), 23753-13759.

789

791 with cosmogenic ${ }^{10} \mathrm{Be}$ in the Gurvan Bogd mountain (Gobi-Altay, Mongolia): climatic and 792 tectonic implications. Terra Nova 17, 278-285, doi: 10.1111/j.1365-3121.2005.00612.x.

793

794

795

796

797

798

799

800

801

802

803

804

805

806

807

808

809

basin scale from cosmogenic nuclides in river sediment. Earth Planet. Sci. Lett. 242, 224-239.

Vassallo, R., 2006. Chronologie et évolution des reliefs dans la région MongolieSibérie: Approche Morphotectonique et géochronologique. $\mathrm{PhD}$ thesis, Université Montpellier 2, $260 \mathrm{p}$.

Vassallo, R., Ritz, J-F., Braucher, R., Jolivet, M., Chauvet, A., Larroque, C., Carretier, S., Bourlès, D., Sue, C., Todbileg, M., Arzhannikova, N., Arzhannikov, S., 2007a. Transpressional tectonics and stream terraces of the Gobi-Altay, Mongolia. Tectonics 26, TC5013, doi:10.1029/2006TC002081.

Vassallo, R., Jolivet, M., Ritz, J-F., Braucher, R., Larroque, C., Sue, C., Todbileg, M., Javkhlanbold, D., 2007b. Uplift age and rates of the Gurvan Bogd system (Gobi-Altay) by apatite fission track analysis. Earth Planet. Sci. Lett. 259, 333-346, doi:10.1016/j.eps1.2007.04.047.

Von Blanckenburg, F., 2006. The control mechanisms of erosion and weathering at 
812 cosmogenic radionuclide dynamics in landslide-dominated drainage basins. J. Geophys. Res.

\section{$816 \quad$ Figure captions}

817 Figure 1: A) Sketch map of the Asian continent with the main tectonic lineations and localization of Ih Bogd massif (black rectangle) in the Gobi-Altay range. B) 3D view of the Ih Bogd massif on a Landsat image. Main active faults and Bitut catchment/fan system are 820 shown.

822 Figure 2: 3D view of the Bitut catchment on a SPOT image. Colored circles (squares for 823 bedrock) represent the measured ${ }^{10} \mathrm{Be}$ concentrations corresponding to the different landforms or single clasts (this study and Vassallo et al., 2007). Values for piedmont P0 and for terraces $\mathrm{T} 1, \mathrm{~T} 2$ and $\mathrm{T} 3$ at the outlet are weighted means.

Figure 3: Bitut catchment geomorphology is dominated by river incision and mass wasting. This leads to the formation of stepped strath terraces (A and B), canyons (B) and landslides of different sizes that dam the river creating small lakes or ephemeral basins along the valley (C). Dashed zone in figure C corresponds to the topography before the last landslide occurred

831 (pictures by R. Vassallo).

832

833 Figure 4: Picture of boulder corridors starting from the edges of the summit plateau (picture by R. Braucher). 
836 Figure 5: Stepped strath terraces at the outlet of the catchment with their mean ${ }^{10} \mathrm{Be}$

837 concentrations (picture by C. Larroque). Note that values increase from the youngest terrace

838 T4 to terrace T2 and then decrease for terrace T1, whose tread is slightly steeper than the

839 others and is affected by a higher denudation rate.

840

841 Figure 6: A) Plot of the ${ }^{10} \mathrm{Be}$ concentrations as a function of the altitude and of the relative

842 distance along the main Bitut valley. B) Histograms of the single clast concentrations for 843 strath terraces (T) and active alluvia (A) and colluvia (C). Samples shown in a pale color and 844 marked by an asterisk were not taken into account for the calculation of the weighted means.

846 Figure 7: A) Distribution of the ${ }^{10} \mathrm{Be}$ concentrations on the summit plateau and on the 847 surrounding slopes (pictures by R. Vassallo and M. Jolivet). Note the concentration 2 orders 848 of magnitude higher in the central part than on the edge and the progressive increase in 849 concentrations downslope in the colluvia. B) Detail of the plateau morphology and of the 850 bedrock sampled (IB001).

852 Figure 8: Picture of the canyon down-cutting strath terrace T4 (picture by A. Chauvet). Even 853 though the vertical bedrock wall is supposed to be exposed to cosmic rays for the same period 854 as the alluvial cover, after river incision and terrace abandonment, the former has a 855 concentration 10 times lower than the latter.

857 Figure 9: Evolution of the tread of an alluvial deposit. Starting from a bar-and-swale 858 morphology, the denudation of the surface flattens the deposit and exhumes clasts of different sizes. The initial depth and size of the clasts determine the relative time of their exhumation among the others and the chances of preservation in the original position during the 
861 denudation of the deposit. Distribution pattern of the desert varnish on the outcropping part of

862 the clasts is an important indication of their limited remobilization after the deposit.

864 Figure 10: Panorama of the lower reaches of the Bitut river with the position of the four main 865 strath terraces (picture by J-F. Ritz). In the close-up, picture of sample MO05-08, whose 866 desert varnish distribution shows the thickness of the recent denudation (picture by R. 867 Braucher). Mean ${ }^{10} \mathrm{Be}$ concentration of terrace T3 at the outlet is up to 3 times higher than upstream. Values are systematically lower than expected when slopes are steeper (the same consideration can be applied to $\mathrm{T} 1$ and $\mathrm{P} 0$, see text).

870

871 Figure 11: Diagram of the evolution of the ${ }^{10} \mathrm{Be}$ concentration through time for three different 872 inheritances, for given production and denudation rates. The measured ${ }^{10} \mathrm{Be}$ concentration of a 873 sample, depending on the inheritance, may either correspond to a steady-state value for a 425

874 ka minimum age (green curve, no inheritance), or to non steady-state values with much lower 875 minimum ages (red and blue curves, inheritances are respectively 8 and $15 \%$ of the total 876 concentration).

877

878 Table 1: Results of the ${ }^{10} \mathrm{Be}$ analysis. Calibration against NIST Standard Reference Material 879

880 scaling functions of Lal (1991) and a modern ${ }^{10} \mathrm{Be}$ production rate in quartz of $4.5 \pm 0.3$ 881 at/g/yr at sea level and high latitude. Data from this study are marked by symbol $\S$. Outlying 882 data marked by symbol * have not been taken into account for the calculation of the surfaces 883 weighted means (see text). 